\title{
Mononuclear cell complement receptor blockade in primary biliary cirrhosis
}

\author{
M N A AL-AGHBAR, J NEUBERGER, ROGER WILLIAMS, \\ AND A L W F EDDLESTON \\ From the Liver Unit, King's College Hospital and Medical School, Denmark Hill, London
}

SUmmary Peripheral blood monocyte and lymphocyte receptors for $\mathrm{Fc}$ and $\mathrm{C}_{3} \mathrm{~b}$ fragments were examined in vitro in patients with primary biliary cirrhosis and other chronic liver diseases using sheep red blood cells coated with anti-SRBC $\operatorname{IgG}_{1}$ (to detect Fc receptors) and with anti-SRBC IgM and complement (to detect $\mathrm{C}_{3} \mathrm{~b}$ receptors). The number of $\mathrm{C}_{3} \mathrm{~b}$ receptors detected on 100 monocytes was significantly lower in patients with primary biliary cirrhosis $(23 \cdot 0 \pm 12 \cdot 0$, mean \pm 1 SD) compared with normal controls $(57 \cdot 4 \pm 16.9)$ and other chronic liver disease (HBsAg negative chronic active hepatitis $62 \cdot 0 \pm 17 \cdot 0$, alcoholic cirrhosis $50 \cdot 9 \pm 4 \cdot 0$ ), while the number of Fc receptors detected on 100 monocytes was not significantly different in all the groups (primary biliary cirrhosis $72 \cdot 8 \pm 28 \cdot 6$, chronic active hepatitis $74 \cdot 7 \pm 14 \cdot 0$, alcoholic cirrhosis $58 \cdot 0 \pm 13 \cdot 5$ and normal controls $69 \cdot 6 \pm 19 \cdot 9$ ). When mononuclear cells isolated from normal individuals were pre-incubated with serum from patients with primary biliary cirrhosis before testing their receptor function there was a significant reduction in the number of $\mathrm{C}_{3} \mathrm{~b}$ receptors detected per 100 monocytes $(27 \cdot 6 \pm 10 \cdot 8)$ compared with pre-incubation with normal serum $(72 \cdot 0 \pm 18 \cdot 0)$. This reduction in $\mathrm{C}_{3}$ b-receptor function was again observed when the serum used for pre-incubation was depleted of circulating immune complexes; but when complement was further depleted from these sera, the number of $\mathrm{C}_{3}$ b-receptors detected after pre-incubation was similar to normal values $(64 \cdot 0 \pm 11 \cdot 8)$. Lymphocyte receptors showed a similar pattern of results. This implies a specific $\mathrm{C}_{3} \mathrm{~b}$ receptor blockade on monocytes and lymphocytes from patients with primary biliary cirrhosis which appears to be because of blocking by serum factor(s) including complement fragments.

Numerous abnormalities of immune function have been reported in patients with primary biliary cirrhosis. These include hypergammaglobulinaemia especially of IgM, raised levels of circulating immune complexes, anergy and impaired suppressor cell function for both T-B and T-T cellular interactions. ${ }^{1}$ The extent to which these abnormalities may contribute either to the pathogenesis or to the progression of the disease is not clear. A further abnormality is an impairment of the reticuloendothelial system. Jaffe and his colleagues ${ }^{2}$ studied the clearance of autologous radio-chromium labelled red cells in patients with primary biliary cirrhosis and other chronic liver diseases and found a specific defect in the $\mathrm{C}_{3}$ b-receptor mediated

Address for correspondence: Dr Roger Williams. The Liver Unit, Kings College Hospital and Medical School, Denmark Hill, London SE5 8RX. Received for publication 12 March 1984 clearance of red cells only in patients with primary biliary cirrhosis. The clearance of IgG-coated red cells and aggregated albumin particles was normal, implying that these patients have a normal clearance of $\mathrm{Fc}$ receptor-mediated particles and immunologically inert particles.

As the failure of clearance of $\mathrm{C}_{3} \mathrm{~b}$-coated red cells in vivo could be because of blocking of $\mathrm{C}_{3} \mathrm{~b}$ receptors by serum factors, the present study was designed to examine directly in vitro $\mathrm{Fc}$ and $\mathrm{C}_{3} \mathrm{~b}$ receptors on the peripheral blood mononuclear cells in patients with primary biliary cirrhosis and other chronic liver diseases, including autoimmune chronic active hepatitis.

\section{Methods}

SUBJECTS

Ten healthy laboratory volunteers, seven of whom 
were men, served as normal controls. None had a history of excess alcohol ingestion or previous hepatitis. The mean age was 30 years (range 28-41 years). Of the 13 patients with primary biliary cirrhosis investigated all had liver histology diagnostic of the disease. ${ }^{3}$ Four patients were in the early stages of primary biliary cirrhosis (stage I and II) and the remainder were in the late stages (III and IV). Twelve were women and the median age was 59 years (range 34-70 years). Four patients were taking d-Penicillamine $1.2 \mathrm{~g}$ daily in a controlled clinical trial and the remainder were not receiving any specific immunomodulatory drugs at the time of the study.

Nine patients with HBsAg negative chronic active hepatitis were studied. The diagnosis was made on internationally agreed histological criteria ${ }^{4}$ and all had established cirrhosis. Eight of these patients were men and ages ranged from 30 to 72 years (median 50 years). One patient was not receiving any specific therapy at the time of the study and the remaining eight were taking prednisolone $10-20 \mathrm{mg}$ daily and azathioprine $75 \mathrm{mg}$ daily.

Nine patients with alcoholic liver disease were studied; all were men and the median age was 57 years (range 39-78 years). All had taken more than $100 \mathrm{~g}$ ethanol daily for more than four years and all had features of alcoholic cirrhosis on liver biopsy. ${ }^{5}$ Patients were studied after a minimum period of two weeks as hospital inpatients during which time they had abstained from alcohol.

ISOLATION OF PERIPHERAL BLOOD MONOCYTES Peripheral blood mononuclear cells were isolated from whole blood by dextran sedimentation and Ficoll-Triosil density centrifugation. ${ }^{6}$ Mononuclear cell-enriched plasma was then incubated in a Petri dish (Sterilin) for 45 minutes at $37^{\circ} \mathrm{C}$ to allow adherence of monocytes. The supernatant was discarded and the adherent cells were gently harvested using a rubber policeman. The cells were then washed three times in Hank's balanced salt solution (Wellcome Reagents Ltd) and resuspended at a concentration of $10^{6}$ cells $/ \mathrm{ml}$ in $20 \%$ heat inactivated fetal calf serum (Gibco) and RPMI 1640 (Gibco) containing L-glutamine, penicillin $200 \mathrm{IU} /$ $\mathrm{ml}$, streptomycin $100 \mu \mathrm{g} / \mathrm{ml}$ and amphotericin (Squibb) $2 \mu \mathrm{g} / \mathrm{ml}$. In order to prevent adherence of monocytes to the test tubes, siliconised glass tubes were used throughout prepared by treating the tubes with Repelcote (Hopkin and Williams). At the end of the isolation procedure the median purity of monocytes was $46 \%$ (range $40-50 \%$ ) as measured by peroxidase staining, and the viability as determined by trypan blue exclusion was greater than $95 \%$.
OPSONISATION OF SHEEP RED BLOOD CELLS WITH ANTI-SRBCIgG 1 (SRBC-IgG)

Sheep red blood cells in Alsevers solution (Tissue Culture Services Ltd) were washed three times in $0.9 \%$ sodium chloride and diluted to give a final concentration of $2.5 \times 10^{8} / \mathrm{ml}$. The suboptimal agglutinating concentration of anti-SRBC-IgG (Sera Laboratories Ltd) was determined by titration. Equal volumes of sheep red blood cells and anti-SRBC-IgG ${ }_{1}$ were mixed and incubated for 30 minutes at $37^{\circ} \mathrm{C}$. The coated sheep red cells were then washed three times in $0.9 \%$ sodium chloride and resuspended in the original volume.

OPSONISATION OF SHEEP RED BLOOD CELLS BY ANTI-SRBC-IgM AND COMPLEMENT (SRBC-M-C) The suboptimal agglutinating concentration of antiSRBC-IgM (Sera Laboratories Ltd) was determined by titration and was used to coat the sheep red blood cells as described above. These cells were then coated with complement using equal volumes of IgM coated sheep red blood cells and fresh human serum, used at a dilution of subminimal lysis, by incubating at $37^{\circ} \mathrm{C}$ for 30 minutes. The SRBC-M-C were then washed three times in $0.9 \%$ sodium chloride and resuspended to the original volume.

ASSAY OF MONOCYTE RECEPTOR FUNCTION

Round glass cover slips $13 \mathrm{~mm}$ diameter (Chance Poppers) were placed in each well of a multi-well tissue culture plate $2 \mathrm{~cm}^{2}$ in diameter (Falcon). Five hundred microlitres of monocyte-enriched suspension (at $10^{6}$ cells $/ \mathrm{ml}$ ) were placed on the cover slip and incubated for 45 minutes at $37^{\circ} \mathrm{C}$ to allow adherence of the monocytes to the cover slips. One hundred microlitres of either sheep red blood cells, SRBC-IgG, SRBC-M or SRBC-M-C (at a concentration of $250 \times 10^{6}$ cells $/ \mathrm{ml}$ ) was then added to each well in duplicate and incubated for 30 minutes at $37^{\circ} \mathrm{C}$ in humidified atmosphere containing $5 \%$ carbon dioxide, $12 \%$ oxygen, and $83 \%$ nitrogen. The non-adherent cells were removed by gentle washing of the cover slips in $0.9 \%$ sodium chloride, the remaining cells were fixed with $100 \%$ methanol, stained with $10 \%$ Giemsa, washed in water, dried in air, and fixed on glass slides. Monocytes were identified morphologically and the number of sheep red blood cells attached to 100 monocytes were counted in four random fields without the observer having knowledge of the nature of the cells on the slide.

INCUBATION OF SERUM WITH PERIPHERAL BLOOD MONOCYTES

In order to study the effect of prior incubation of serum with peripheral blood monocytes on receptor 
function of monocytes from normal individuals, blood was withdrawn from patients with primary biliary cirrhosis and normal controls and allowed to clot for two hours at $37^{\circ} \mathrm{C}$, the serum was removed by 10 minutes centrifugation at $1100 \mathrm{~g}$ and stored at $-20^{\circ} \mathrm{C}$. Monocyte enriched suspension from normal controls (at a concentration of $10^{6} / \mathrm{ml}$ ) was divided into two aliquots, which were incubated for 30 minutes at $37^{\circ} \mathrm{C}$ in a $2: 1 \mathrm{v} / \mathrm{v}$ dilution of serum from either normal subjects or patients with primary biliary cirrhosis. The cells were then washed three times in Hank's balanced salt solution and resuspended in a final concentration of $10^{6}$ cells $/ \mathrm{ml}$ in $20 \%$ FCS in RPMI. These cells were then used in the receptor function assay as described above.

\section{REMOVAL OF CIRCULATING IMMUNE COMPLEXES FROM THE SERUM}

In order to determine the effect of circulating immune complex-free serum on receptor function of monocytes from normal subjects, serum from patients with primary biliary cirrhosis and normal controls was treated with polyethylene glycol 6000 (Hopkin and Williams) ${ }^{8}$ Briefly, $6 \mathrm{ml}$ of $20 \%$ polyethylene glycol in veronal buffered saline were mixed with $3 \mathrm{ml} 0.2 \mathrm{M}$ EDTA and $1 \mathrm{ml}$ veronal buffered saline. This mixture was added to serum in a final concentration of $2 \%$ polyethylene glycol; after overnight incubation at $4^{\circ} \mathrm{C}$, the mixture was centrifuged at $1720 \mathrm{~g}$ for 20 minutes at $4^{\circ} \mathrm{C}$. The supernatant was collected in ice in separate tubes.

REMOVAL OF COMPLEMENT $\left(c_{3}\right)$ FROM THE SERUM After depletion of circulating immune complexes from the serum, further removal of $\mathrm{C}_{3}$ was performed according to Hudson and Hay. ${ }^{9}$ Five hundred milligrams of zymosan (Sigma) were dissolved in $50 \mathrm{ml} 0.9 \%$ sodium chloride at $100^{\circ} \mathrm{C}$ for 5 minutes, then centrifuged at $500 \mathrm{~g}$ for 10 minutes at $18^{\circ} \mathrm{C}$. The supernatant was discarded and $10 \mathrm{ml}$ of circulating immune complexes depleted serum was added to the precipitate, mixed, and incubated for one hour at $37^{\circ} \mathrm{C}$, the suspension was spun at $1720 \mathrm{~g}$ for 20 minutes at $18^{\circ} \mathrm{C}$ and the supernatant was recovered. This procedure was repeated three times to ensure exhaustion of $\mathrm{C}_{3}$ and its degradation product $\mathrm{C}_{3} \mathrm{~b}$. Multiple zymosan treatments depleted completely $\mathrm{C}_{3}$ and $\mathrm{C}_{3}$ b from sera obtained from both patients with primary biliary cirrhosis and normal controls as assessed by cross immunodiffusion.

STATISTICAL METHODS

Wilcoxon's rank sum test for paired and unpaired values was used.

\section{Results}

\section{MONOCYTE RECEPTOR FUNCTION}

There was minimal binding of untreated sheep red blood cells and IgM coated sheep red blood cells to 100 monocytes isolated from controls $(5 \cdot 0 \pm 1 \cdot 7$, mean \pm 1 SD and $5 \cdot 8 \pm 2 \cdot 0$ respectively) and from the patients with liver disease: primary biliary cirrhosis $6.0 \pm 3.6$ and $5.4 \pm 1 \cdot 6$, chronic active hepatitis $5 \cdot 0 \pm 3 \cdot 3$ and $5 \cdot 5 \pm 2 \cdot 0$ and alcoholic liver disease $4.5 \pm 1.0$ and $6.5 \pm 1.0$ respectively. There was no significant difference between the number of $\mathrm{IgG}_{1}$ coated sheep red blood cells attached to 100 monocytes isolated from controls $(69 \cdot 6 \pm 19.9)$ and monocytes isolated from patients with liver diseases: primary biliary cirrhosis $(72 \cdot 8 \pm 28 \cdot 6)$, chronic active hepatitis $(74.7 \pm 14 \cdot 0)$ and alcoholic liver disease $(58 \cdot 0 \pm 13 \cdot 5)$ (Fig. 1).

When the $\mathrm{C}_{3} \mathrm{~b}$ receptor function was tested using IgM and complement coated sheep red blood cells, however, the number of such coated red cells attached to 100 monocytes from patients with primary biliary cirrhosis $(23 \cdot 0 \pm 12 \cdot 0)$ was significantly lower than the number attached to 100 monocytes from normal controls $(57 \cdot 4 \pm 16 \cdot 9)$ $(p<0.01)$ or other liver disease groups: chronic active hepatitis $(62 \cdot 0 \pm 17 \cdot 0)$ and alcoholic liver disease $(50.9 \pm 4 \cdot 0)(\mathrm{p}<0 \cdot 01)$ (Fig. 1).

Pre-incubation of serum from patients with primary biliary cirrhosis with mononuclear cells isolated from normal individuals had no effect on Fc-receptor function. The mean number of $\mathrm{IgG}_{1}$ coated sheep red blood cells attached to 100 monocytes was unchanged after incubation with serum from patients with primary biliary cirrhosis $(55.8 \pm 8.9)$ compared with pre-incubation with serum from normal individuals $(59 \cdot 8 \pm 11 \cdot 0)$. When the $\mathrm{C}_{3} \mathrm{~b}$ receptor function was studied using IgM and complement coated sheep red blood cells, however, there was a significant reduction in the number of SRBC-M-C attached to 100 monocytes after preincubation with serum from patients with primary biliary cirrhosis $(27.6 \pm 10.8)$ compared with preincubation with control serum $(72 \cdot 0 \pm 18 \cdot 0)(\mathrm{p}<0 \cdot 05)$ (Fig. 2).

The number of IgM and complement coated sheep red blood cells attached to 100 normal monocytes remained significantly lower after preincubation with circulating immune complexesdepleted serum from patients with primary biliary cirrhosis $(32 \cdot 0 \pm 10 \cdot 0)$ when compared with circulating immune complexes-depleted control serum $(78.0 \pm 12.9)(\mathrm{p}<0.05)($ Fig. 2). In contrast the Fc receptor function of normal monocytes was unaltered by prior incubation with circulating immune complexes-depleted serum from either 


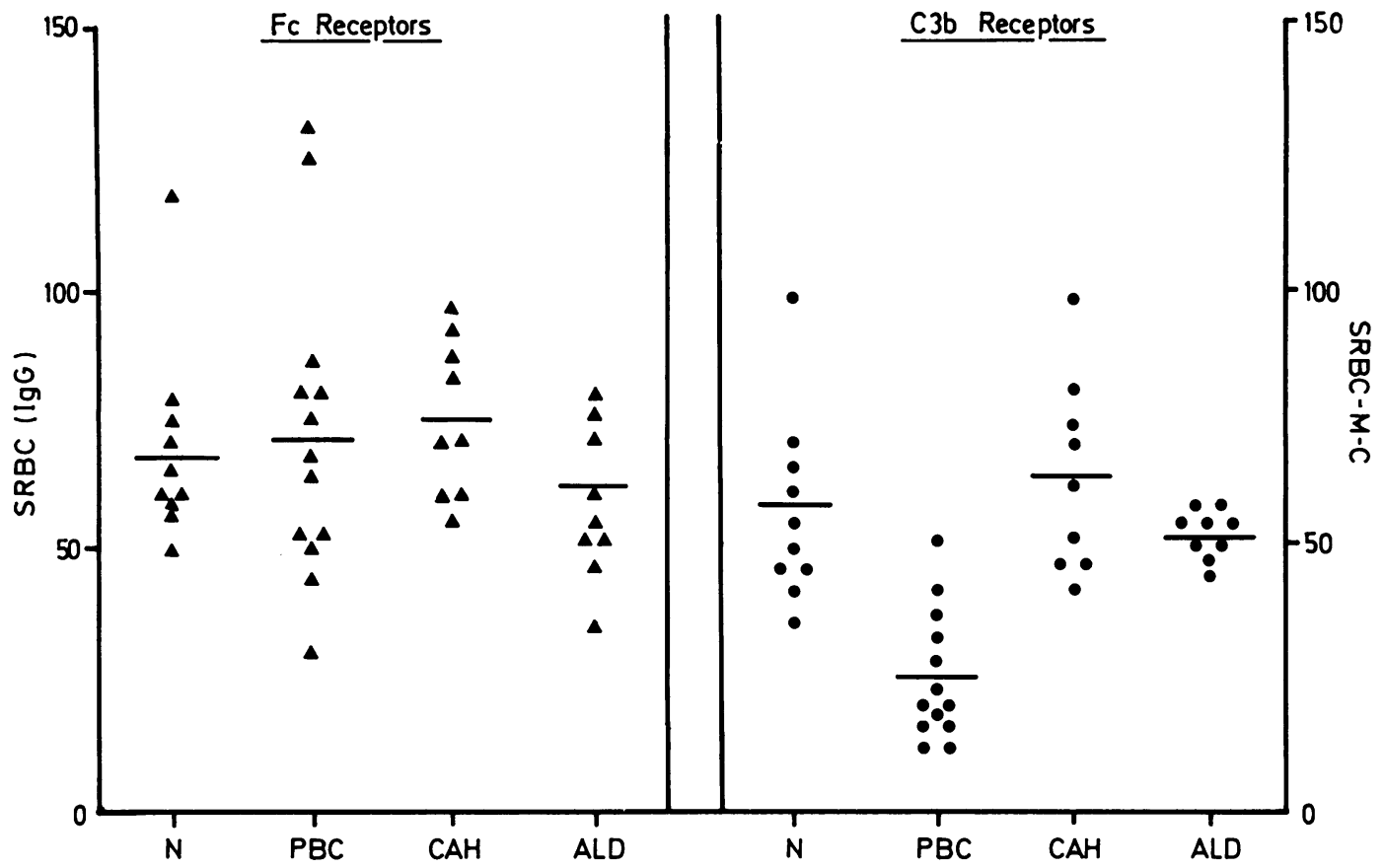

Fig. $1 F c$ and $C_{3} b$ receptor function of monocytes isolated from normal controls $(N C)$, primary biliary cirrhosis ( $\left.P B C\right)$, chronic active hepatitis $(C A H)$ and alcoholic liver disease $(A L D)$. Horizontal bars represent the means.

normal or primary biliary cirrhosis patients $(67 \cdot 0 \pm 10$ SRBC-IgG $1 / 100$ monocytes and $65 \cdot 5 \pm 9 \cdot 0$ respectively). No effect of $\mathrm{C}_{3}$ depletion of primary

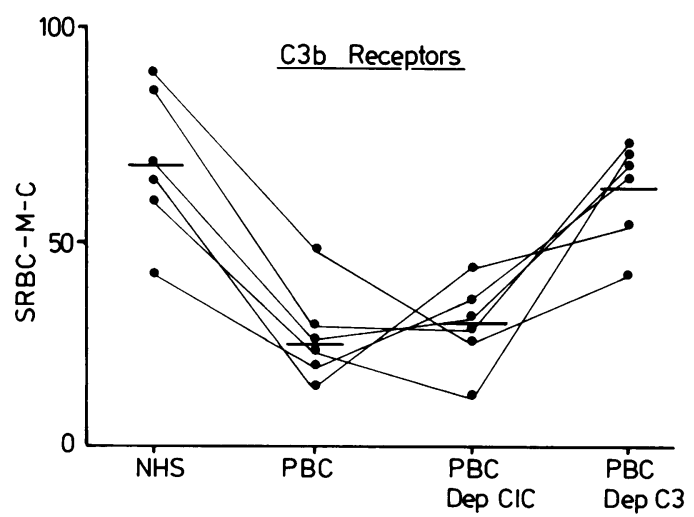

Fig. 2 Effect on monocyte $C_{3} b$ receptor function of prior incubation of normal monocytes with normal serum and serum from patients with primary biliary cirrhosis $(P B C)$ and after depletion of circulating immune complexes $(P B C$ dep CIC) and complement (PBC dep $C_{.3}$ ). Horizontal bars represent the means. biliary cirrhosis serum on $\mathrm{Fc}$ receptor function of normal monocytes was observed. The number of SRBC-IgG ${ }_{1}$ attached to 100 normal monocytes was $57 \cdot 0 \pm 5 \cdot 0$ using $C_{3}$ depleted primary biliary cirrhosis serum compared with $65 \cdot 9 \pm 9 \cdot 0$ before zymosan treatment and $71 \cdot 6 \pm 8 \cdot 0$ using $C_{3}$ depleted normal serum. In contrast, the $\mathrm{C}_{3} \mathrm{~b}$ receptor function was found to be normal after zymosan treatment (64.0 $\pm 11 \cdot 8$ SRBC-M-C/100 monocytes compared with $32 \cdot 0 \pm 10 \cdot 0$ before zymosan treatment $(p<0 \cdot 05)$ (Fig. 2), with zymosan treated and untreated normal serum was not significantly different $(81 \cdot 5 \pm 15 \cdot 0$ and $78 \cdot 0 \pm 12 \cdot 9$ respectively).

\section{LYMPHOCYTE RECEPTOR FUNCTION}

Lymphocytes remaining attached to petri dish were also examined for $\mathrm{Fc}$ and $\mathrm{C}_{3} \mathrm{~b}$ receptors after the various procedures described above. The results are summarised in Tables 1 and 2 . The mean number of Fc receptors for $\operatorname{IgG}_{1}\left(\mathrm{Fc} \gamma_{1}\right.$ receptors) on the lymphocytes was similar in all the groups, whereas the mean number of $\mathrm{C}_{3} \mathrm{~b}$ receptors was lowest on the lymphocytes from patients with primary biliary cirrhosis. The $\mathrm{C}_{3} \mathrm{~b}$ receptors of normal lymphocytes could be masked in this assay be pre-incubation of mononuclear cells with serum from patients with 
Table $1 \quad F c \gamma_{1}$ and $C_{3} b$ receptor function of adherent lymphocytes isolated from normal controls and patients with primary biliary cirrhosis, chronic active hepatitis and alcoholic liver disease

\begin{tabular}{lll}
\hline Lymphocytes from & $\begin{array}{l}\text { FC } \gamma_{1} \text { receptors } \\
\left(S R B C-I g G_{1}\right)\end{array}$ & $\begin{array}{l}C_{3} \text { b receptors } \\
(S R B C-M-C)\end{array}$ \\
\hline Normal control (10) & $21 \cdot 4 \pm 5 \cdot 9$ & $79 \cdot 2 \pm 36 \cdot 4$ \\
Primary biliary cirrhosis (13) & $14 \cdot 9 \pm 4 \cdot 2$ & $15 \cdot 7 \pm 7 \cdot 5^{*}$ \\
Chronic active hepatitis (9) & $18 \cdot 2 \pm 6 \cdot 4$ & $68 \cdot 8 \pm 25 \cdot 9$ \\
Alcoholic liver disease (9) & $15 \cdot 3 \pm 4 \cdot 6$ & $75 \cdot 6 \pm 31 \cdot 4$ \\
\hline
\end{tabular}

${ }^{*} \mathrm{p}<0.01$ compared with control lymphocytes; figures given are mean $\pm 1 \mathrm{SD}$.

primary biliary cirrhosis, and the factor(s) responsible for this was not precipitated by polyethylene glycol treatment but could be depleted by treatment of the serum with zymosan.

\section{Discussion}

Phagocytosis by monocytes and macrophages remains poorly understood, although some of the processes involved are becoming clearer. Opsonised particles are attached to and ingested by means of receptors on the phagocytes. These receptors include both the $\mathrm{Fc}$ receptors which bind the $\mathrm{Fc}$ portion of aggregated or antigen complexed $\mathrm{IgG}^{10}$ and the complement receptors that bind particles coated with $\mathrm{C}_{3} \mathrm{~b} .{ }^{11}$ Cooperation between these two receptors is necessary for efficient phagocytosis and blockade of either of these two receptors will reduce the phagocytic capacity. ${ }^{12}$ Patients with primary biliary cirrhosis, as with other chronic liver diseases investigated in this study, have normal functioning Fc receptors as assessed in our assay but, in contrast with the patients in the other groups, these patients have defective $\mathrm{C}_{3} \mathrm{~b}$ receptor function. While this

Table 2 Effect of lymphocyte $F c \gamma_{1}$ and $C_{3} b$ receptor function of prior incubation of normal lymphocytes with normal serum and serum from patients with primary biliary cirrhosis $(P B C)$ and after depletion of circulating immune complexes $(C I C)$ and complement $\left(C_{3}\right)$

\begin{tabular}{lcc}
$\begin{array}{l}\text { Lymphocytes from normal } \\
\text { control after pre-incubation }\end{array}$ & $\begin{array}{c}\text { Fc } \gamma_{1} \text { receptors } \\
\left(S R B C-\lg G_{l}\right)\end{array}$ & $\begin{array}{c}C_{3} \text { b receptors } \\
(S R B C-M-C)\end{array}$ \\
\hline Normal human serum (6) & $20 \pm 5 \cdot 6$ & $78 \cdot 6 \pm 20$ \\
PBC serum & $17 \pm 6 \cdot 4$ & $36 \cdot 3 \pm 10 \cdot 7^{*}$ \\
NHS depleted CIC (6) & $16 \cdot 3 \pm 6 \cdot 6$ & $98 \pm 13 \cdot 6$ \\
PBC sera depleted CIC (6) & $13 \cdot 5 \pm 3 \cdot 8$ & $26 \pm 5^{*}$ \\
NHS depleted CIC and C $3(6)$ & $21 \pm 4 \cdot 5$ & $81 \cdot 5 \pm 15$ \\
PBC sera depleted CIC and C & $14 \cdot 5 \pm 3 \cdot 7$ & $76 \pm 12 \cdot 9$ \\
\hline
\end{tabular}

${ }^{*} \mathrm{p}<0 \cdot 05$ compared with controls; figures are mean $\pm \mathrm{SD}$. defective function is likely to be because of blocking by serum factor(s), we were not able to exclude an intrinsic abnormality of the receptor itself. Intracellular assessment of marker molecules would be difficult since the cells will actively resynthesise depleted stores of glutathione and other such markers. Electron microscopy studies of membrane may help in testing this hypothesis. This receptor function defect is associated with a circulating serum factor because zymosan treatment had depleted the patients' sera of factors that block $\mathrm{C}_{3} \mathrm{~b}$ receptors of normal monocytes. The precise nature of this blocking factor is difficult to determine, but probably represents $C_{3}$ or $C_{3} b$. This is because zymosan acts by cleaving $C_{3}$ into $C_{3} a$ and $C_{3} b$ and forming a complex with $\mathrm{C}_{3} \mathrm{~b} .{ }^{13}$ Thus, in a small aliquot of serum, repeated incubation with zymosan and precipitation of the complex by centrifugation will deplete the serum of both $\mathrm{C}_{3}$ and $\mathrm{C}_{3} \mathrm{~b}$ and this was confirmed by immunodiffusion. Indeed, preliminary studies had shown that a single exposure of serum from normal individuals with zymosan and subsequent centrifugation will result in that serum being able to block the $\mathrm{C}_{3}$ b receptor of monocytes from normal individuals.

In vitro manipulation of isolated monocytes may lead to activation of these cells which results in increased expression of receptors. ${ }^{14}$ An alternative explanation for these results is that $\mathrm{C}_{3} \mathrm{~b}$ receptors on monocytes from patients with primary biliary cirrhosis were not fully activated during isolation as were monocytes from the other groups. This is unlikely, however, because serum from patients with primary biliary cirrhosis could block $\mathrm{C}_{3} \mathrm{~b}$ receptors on monocytes from normal subjects.

Schreiber $e t$ al ${ }^{15}$ found that hydrocortisone and prednisolone could inhibit in vitro both $F_{c}$ and $C_{3} b$ receptor function on monocytes from normal individuals. In our study, however, eight patients with chronic active hepatitis on corticosteroid therapy showed normal monocyte receptor function. These workers were using a concentration of corticosteroids a thousand times higher than those likely to be present in the serum of these patients.

In primary biliary cirrhosis increased concentrations of circulating immune complex-like activity ${ }^{16}$ and increased catabolism of complement ${ }^{17}$ have been reported. It was shown ${ }^{18}$ that circulating immune complexes of human serum albumin and anti-human serum albumin can cause a dose dependent loss of both $\mathrm{Fc}$ and $\mathrm{C}_{3} \mathrm{~b}$ receptor function on rat Kupffer cells. These complexes are soluble, however, in contrast with those in the sera of patients with primary biliary cirrhosis which are insoluble and have different properties. ${ }^{16}$ It is of interest that there was no difference in the $\mathrm{C}_{3} \mathrm{~b}$ 
receptor function in those patients receiving d-penicillamine compared with those on no specific therapy, even though d-penicillamine therapy may be associated with reduction in circulating immune complexes. ${ }^{19}$ These findings add further support to the results that removal of circulating immune complexes from sera of patients with primary biliary cirrhosis does not alter the ability of the serum to block the $\mathrm{C}_{3} \mathrm{~b}$ receptor on normal monocytes.

The finding that the $\mathrm{C}_{3} \mathrm{~b}$ receptors on lymphocytes isolated from patients with primary biliary cirrhosis are blocked by factors other than immune complexes parallel the results obtained on the monocyte receptors. The lymphocytes studied, however, were those adherent to the petri dishes and are unlikely to be representative of the lymphocyte populations in either the patient's blood or liver. Nevertheless, the results do suggest that at least some of the factors which block the monocyte $\mathrm{C}_{3} \mathrm{~b}$ receptors may block some of the lymphocyte $\mathrm{C}_{3}$ b receptors.

While the pathogensis of primary biliary cirrhosis remains unclear, defective phagocytosis caused by impaired $\mathrm{C}_{3} \mathrm{~b}$ receptor function may lead to persistence of antigenic challenge and increase in antibody production. This may result in the formation of increased concentrations of circulating immune complexes which may lead to complement activation and granuloma formation, ${ }^{20}$ and could contribute to the pathogenesis of the disease.

$\mathrm{JN}$ is a Wellcome clinical research fellow. We are indebted to $\mathrm{Dr}$ Diego Vergani, Department of Immunology, King's College Hospital for technical advice and to Linda Rimmer for editorial assistance.

\section{References}

1 James SP, Vierling JM, Strober W. The role of immune response in the pathogenesis of primary biliary cirrhosis. Semin Liver Dis 1981; 1: 4: 322-37.

2 Jaffe C, Vierling JM, Jones EA, Lawley TJ, Frank MM. Receptor specific clearance by reticuloendothelial system in chronic liver disease. Demonstration of defective $\mathrm{C}_{3} \mathrm{~b}$ specific clearance in primary biliary cirrhosis. J Clin Invest 1978; 62: 1069-77.

3 Scheuer PJ. Primary biliary cirrhosis. Proc $R$ Soc Med 1967: 60: 1257-60.

4 Anthony PP, Ishak KG, Nayak NC, Poulsen HB, Scheuer PJ, Sobin IH. The morphology of cirrhosis. Recommendation of definition, nomenclature and classification by a working party sponsored by WHO. $J$ Clin Pathol 1978; 31: 395-414.
5 Review by an international group. Alcoholic liver disease - morphological manifestations. Lancet 1981; 1: 707-11.

6 Boyum A. Isolation of mononuclear cells and granulocytes from human blood. Scand J Clin Lab Invest 1968; 21: suppl 97: 77-108.

7 Graham RC, Karnowsky MJ. The early stages of absorption of injected HROP in the proximal tubules in mouse kidney. Ultrastructural cytochemistry by a new technique. J Histochem Cytochem 1966; 14: 291-302.

8 Creighton WD, Lambert PH, Miescher PA. Detection of antibodies and soluble antigen-antibody complexes by precipitation with polyethylene glycol. J Immunol 1973; 11: 1219-27.

9 Hudson L, Hay FC. Practical immunology. 2nd ed. Oxford: Blackwell, 1980: 146.

10 Reynolds HY, Atkinson HP, Newball HH, Frank MM. Receptors for immunoglobulin and complement on human alveolar macrophages. J Immunol 1975; 114: 1813-919.

11 Mantovani B, Rabinovitch M, Nussenzweig V. Phagocytosis of immune complexes by macrophages. Different roles of macrophage receptor sites for complement (3) and for immunoglobulin (IgG). J Exp Med 1972; 135: 780-92.

12 Hakanson L, Venge P. Kinetic studies of neutrophil phagocytosis. V Studies on the co-operation between Fc and $\mathrm{C}_{3} \mathrm{~b}$ receptors. J Immunol 1982; 47: 687-94.

13 Nicholson A, Brade V, Lee GD, Shin HS, Mayer MM. Kinetic studies of the formation of properdin system enzymes on zymosan: evidence that nacent $\mathrm{C}_{3} \mathrm{~b}$ controls the rate of assembly. J Immunol 1974; 112: 1115-23.

14 Bianco C, Green FM, Silverstein SC. Studies on the macrophage complement receptors. Alteration of receptor function upon macrophage activation. $J$ Exp Med 1975; 141: 1278-90.

15 Schreiber AD, Parsons J, McDermot P, Cooper RA. Effect of corticosteroids on the human monocytes IgG and complement receptors. J Clin Invest 1978; 56: 1189-97.

16 Gupta RC, Dickson ER, McDuffie Bagganestoss AH. Circulating immune complexes in primary biliary cirrhosis. J Exp Immunol 1978; 34: 19-27.

17 Wander JR, Dienstag JL, Bhan AK, Feller ER, Isselbacher KJ. Circulating immune complexes and complement activation in primary biliary cirrhosis. $N$ Engl J Med 1978; 298: 233-7.

18 Nishi T, Bhan AK, Collins AB, McCluskey ET. Effects of circulating immune complexes on $\mathrm{Fc}$ and $\mathrm{C}_{3} \mathrm{~b}$ receptors of Kupffer cells in vivo. Lab Invest 1981; 44: 442-8.

19 Epstein O, Villiers DD, Jain S, Potter BJ, Thomas HC, Sherlock S. Reduction of immune complexes and immunoglobulins induced by d-Penicillamine in PBC. $N$ Engl J Med 1979; 300: 274-8.

20 Spector WG, Heesom N. The production of granuloma by antigen-antibody complexes. J Pathol 1969; 98: 31-39. 